\title{
The impact of the new immigration reform act
}

\author{
Howard R. Rosenberg $\square$ John W. Mamer
}

he Immigration Reform and Control Act of 1986 (IRCA) became law last fall, barely two months after most observers had concluded that the 99th Congress would be unable to reach agreement on its sensitive provisions. A monumental, complex amendment to the Immigration and Nationality Act, the new law addresses related issues of border control, status of undocumented aliens, labor supply and employment practices, civil rights, social services, and administration of the law itself.

The 1986 law was passed "to effectively control unauthorized immigration to the United States" (Conference Committee Report $99-1000$, p. 1). It is based on beliefs that a sovereign nation needs to control its borders, that U.S. borders are out of control, and that those aliens who cross them seek income through employment. The main thrust of the law is therefore to reduce job opportunities for unauthorized aliens by prohibiting employers from hiring them.

Although it affects all employers and employees in the nation, the act will have its greatest impact on illegal aliens and their employers, many of whom farm in California. Under the act, employers are now prohibited from hiring unauthorized aliens, but many aliens who have lived or worked here illegally can acquire legal status. Special provisions in the law are designed to assist producers of perishable crops in making the transition to a legal workforce, and in general, the law contains measures to soften and defer the more substantial adjustments it requires.

The law became effective when signed November 6,1986 , but it gives employers, aliens, and agencies time to learn and adjust to what it requires of them. The U.S. Department of Justice (Attorney General), in cooperation with the Departments of Agriculture, Labor, Health and Human Services, Commerce, and State, has until June 1,1987 , to disseminate forms and information about the law. Drafts of regulations, forms, and procedures are currently being circulated for public comment. Those affected by the Immigration Reform and Control Act will need to understand the act and its provisions, but the law is not yet entirely clear. While it specifies timetables, penalties, and implementation guidelines, it also directs gov- ernment agencies to develop many operating regulations. Statutory amendments and judicial decisions will undoubtedly further clarify the law in the coming years.

\section{Employer sanctions}

The $\mathbf{1 9 8 6}$ act makes it illegal for anybody to knowingly hire, recruit, or refer for a fee an alien not authorized to work in the United States. It requires employers to inspect documents that show the identity and the authorization to work in the United States of every employee hired after November 6,1986 . It requires the employer to sign and retain a form stating what documents have been so examined, and the employee to sign a form attesting that he or she has legal status. Violations can bring heavy penalties, $\$ 250$ to $\$ 10,000$ and even imprisonment for each instance of "knowingly hiring" and $\$ 100$ to $\$ 1,000$ for paperwork failures, even in connection with the employment of a citizen.

To discourage employers from avoiding workers who may appear to be from an immigrant group, the new law prohibits most employment discrimination on the basis of national origin or citizenship, with specified limited exceptions. It directs the Comptroller General to report annually for three years to Congress on the extent of such discrimination.

\section{Legalization of aliens}

The law provides three mechanisms by which people who have lived or worked illegally in the United States may obtain legal resident status. Two are based primarily on long continuous residence, the third on recent performance of agricultural work.

The first means of legalization updates a previous law. Now anyone who has continously resided in the United States since January 1, 1972 (instead of 1948, as in the earlier law) may petition the local Immigration and Naturalization Service office directly for permanent resident status. The other two means of obtaining legal status, the "general legalization" and "special agricultural worker" (SAW) programs, are newly created by the 1986 law.

An alien is eligible for temporary legal resident status under the general program if he or she (1) has resided continu- ously in the United States in unlawful status since January 1, 1982, (2) has been physically present in the United States since the law took effect on November 6 , 1986 , and (3) is not excluded under other immigration law (e.g., for having been convicted of a felony, endangering national security, being a likely "public charge"). People outside the United States may not apply, even if they have homes here.

The application period for the general program is from May 5, 1987, to May 4, 1988. There are no limits to the number of people who can qualify. Temporary legal status, retained with continuous residence in the United States, is good for only 2 $\frac{1 / 2}{2}$ years, but can convert to permanent resident alien status. An alien will have a 1year period, between 18 and 30 months after obtaining temporary status, to apply for permanent status.

The special agricultural worker program allows adjustment to temporary legal status for many workers who have not been here long enough to qualify for the general program. It is available only to persons who (1) were employed for 90 or more man-days in field work on fruits, vegetables, or other perishable crops between May 1, 1985, and May 1, 1986, and (2) lived in the United States for at least 3 months between May 1, 1985, and May 1, 1986. Neither the work days nor residence months have to be continuous, but they must have occurred during the periods specified. Persons who may have worked extensively in prior years but not for 90 days in seasonal agriculture between May 1,1985 , and May 1, 1986, are not eligible.

The application period for the special agricultural worker program is from June 1,1987 , to November 30,1988 . The first 350,000 applicants who apply and can also show that they (1) performed seasonal agricultural work for at least 90 days from May 1, 1983 to May 1, 1984, and 90 days from May 1, 1984, to May 1, 1985, and (2) resided in the United States for at least 6 months in each of those 12-month periods, will be classified as "Group 1." They will become eligible for conversion to permanent resident alien status after 1 year in temporary status or December 1 , 1989 , whichever is later. Everyone else who meets the basic requirements of this program will be classified as "Group 2" 
and receive permanent resident status after 2 years as a temporary resident alien or December 1, 1990, whichever is later. This program does not require continuous residency to maintain legal status.

Documentary evidence supporting eligibility for legalization will be required under each program. The Immigration and Naturalization Service will accept applications at special legalization centers opening on May 5, 1987. It will also name voluntary organizations and other qualified state, local and community groups as "designated entities" to assist aliens in determining their eligibility and preparing applications for legal status. The new law protects the confidentiality of all transactions between aliens and designated entities.

Aliens who obtain legal temporary or permanent status will be free to live and work anywhere in the United States. The law anticipates the potential departure from agricultural work of even those who qualify under the special agricultural worker program. It allows "replenishment agricultural workers" (RAWs) to enter the United States with temporary legal status each year from 1990 to 1993 if farm labor shortages develop. Secretaries of Agriculture and Labor will be responsible for determining the number of workers, if any, to admit each year by means of a formula that includes the number of workers legalized under the special agricultural worker program, changes in perishable crop acreage, and technological developments. Replenishment workers must work 90 days per year in seasonal agricultural services to maintain temporary legal status. After 3 years, they may obtain permanent resident status and seek employment in any industry. Eligibility for naturalization requires two additional years of employment in seasonal agricultural services

\section{Temporary admission of H-2A workers}

If they cannot meet their labor needs through recruitment from the expanded pool of legal residents, employers can still be certified to hire nonimmigrant workers from outside the United States for temporary or seasonal work. Most agricultural employers have found the existing $\mathrm{H}-2$ visa program impractical. The 1986 law creates a new H-2A classification for temporary farm work and somewhat streamlines the employer certification process. Certification depends on showing that sufficient numbers of qualified workers are not otherwise available and that employment of nonresident aliens would not adversely affect wages and working conditions of other workers in the United States.

Under the new $\mathrm{H}-2 \mathrm{~A}$ program, employers can apply for certification closer to the time (no more than 60 days before) the workers are needed. The new law obligates the Department of Labor to expedite action on employer applications, modified applications that are promptly resubmitted after denial, appeals, and performance failures of domestically recruited workers. It requires certified employers, however, to offer $\mathrm{H}-2 \mathrm{~A}$ workers housing, workers' compensation insurance, and other terms of employment to be defined by the Secretary of Labor. Until at least June 1990, H-2A employers will also have to hire any qualified domestic worker who applies during the first $\mathbf{5 0}$ percent of the certification period.

\section{Enforcement and assessment}

Congress expressed its sense that immigration laws should be vigorously and uniformly enforced, with due regard to constitutional rights, personal safety, and human dignity. While the new law restricts Immigration and Naturalization officers from searching outdoor agricultural operations without the owner's consent or a search warrant, it funds more intensive border patrol activity. The law adds some $\$ 420$ million annually to the Immigration and Naturalization Service appropriation for inspection at the border as well as within the interior. It also authorizes supplementary funds to the Department of Labor for enforcement of wage and hour laws.

The law phases in full enforcement of employer sanctions. No penalties or citations for hiring without documentation are authorized until June 1987. Penalties with respect to the employment of seasonal agricultural workers are not to be imposed until November 1988 (at the end of the SAW application period). Aliens apprehended by the Immigration and Naturalization Service before applying for legalization can avoid deportation and obtain temporary work authorization by presenting a nonfrivolous case for legalization. Individuals who need to travel abroad for emergencies or humanitarian purposes before applying can receive prior authorizatiorsoj do so.

The new immigration law establishes a Commission on Agricultural Workers to report to Congress within five years on the impact of its provisions on agriculture. Among its specific charges is to assess the relationship between agricultural labor management practices and recruitment problems. The law also instructs other government departments to report in coming years on immigration, unauth- orized alien employment and employer sanctions, the $\mathrm{H}-2 \mathrm{~A}$ program, the general legalization program, and cooperative economic development in the Western Hemisphere.

\section{Uncertainties}

Operation and results of the new programs created will be shaped by not only the law itself but also determinations that it has left for administering agencies to make. For example, how "continuous residence" and "perishable agriculture" are defined in the regulations will significantly affect the eligibility of aliens for general and special agricultural worker legalization, respectively. The selection and training of designated entities will surely have a bearing on the number of applications for legal status made and the effectiveness with which they are processed. Clarification of growers' responsibility for verifying legal status of labor contractor employees will influence the propensity to hire directly. Procedures for implementing the new $\mathrm{H}-2 \mathrm{~A}$ requirement to hire domestic workers, even after certification, will affect the popularity and workability of that program, as will the way the Secretaries of Labor and Agriculture use the law's formula to determine the number of replenishment workers to admit each year.

Another set of uncertainties pertains to the performance of government agencies under the law. The vigor and ingenuity with which the Immigration and Naturalization Service and Department of Labor enforce hiring rules and labor standards will be reflected in employer compliance. Whether state employment services take on the task of verifying work authorization of individuals they refer will affect the use that employers make of them.

\section{Choices}

The effectiveness of the Immigration Reform and Control Act of 1986 as public policy will depend mainly on the choices that employers and aliens make. The law contains a complex of incentives and disincentives designed to influence the human behavior that produces illegal immigration.

Whether and how to comply with the law's mandates and prohibitions with respect to hiring is only the most obvious set of issues before employers. Some groups may even challenge the law. Employers intending to avoid violations clearly need to inform themselves and hiring staff about the law, incorporate document checking and the signing of attestation forms into employee selection processes, and adjust personnel record systems. 
Agricultural Experiment Station UNIVERSITY OF CALIFORNIA

Berkeley, California 94720

Lowell N. Lewis, Director

Publication

PENALTY FOR PRIVATE USE, $\$ 300$
BULK RATE

POSTAGE \& FEES PAID USDA

PERMIT No. G269
Other employer efforts, though not required by the 1986 law, may be advantageous under the new regulatory circumstances. They would include (1) assessing the extent of current dependence on unauthorized employees, (2) informing employees about and helping them take advantage of legalization opportunities, and (3) modifying personnel management practices to engender greater employee loyalty and workforce stability.

The main choices before currently unauthorized aliens are whether to pursue legal status when the application period begins and what to do in the meantime. Ironically, successful legalization will require some behavior quite different from that which had enabled aliens to remain and work illegally in the United States before the new law was passed. A continued disposition to avoid the authorities is understandable.

Provision for designated entities to of fer confidential assistance will undoubtedly help potential applicants overcome their reluctance to deal with official immigration processes. Agricultural employers' associations have actively encouraged members to get the word about legalization out to employees. Nevertheless, instances of immigration consultants and attorneys parlaying aliens' fears into large fees for virtually useless consultations are already numerous. Although some specific cases will undoubtedly require legal assistance, the law attempts to spare most applicants the effort and expense of such counsel.

Aliens who do intend to apply for legal status can help themselves by acquiring and organizing documents that will substantiate their eligibility. Once in legal status, their choices of where to seek employment will affect the number of agricultural job opportunities that will potentially draw new immigrants across the border.

Finally, aliens not eligible for legal residence in the United States will continue to face the decision of whether or not to come to or remain in this nation. The new law has, however, changed the costs and benefits attached to their options.

\section{Outcomes to assess}

The Immigration Reform and Control Act of 1986 addresses a national dilemma that has been developing for two decades. Previous legislative neglect has permitted patterns of dependence on unauthorized immigration. Any alteration of a situation to which so many people have adjusted is bound to cause discomfort and meet resistance. The complexity of the new law reflects its makers' efforts to meet the diverse interests of several groups. While the forces that produced immigration reform legislation were inexorable, what the impacts of the new law will be is far from certain.

Some empirical questions on the emerging research agenda are: Will employers refrain from hiring unauthorized aliens? What will distinguish those who do from those who do not? How will agricultural employers alter their personnel management practices to attract and retain employees in a less isolated labor market? What benefits will employers re- alize from assisting aliens in the legalization process? How many aliens will really step forward and apply for legal status? How many and which aliens legalized as special agricultural workers will move to employment outside agriculture? Will farm labor union organizing increase or decrease? Will the flow of new immigrants illegally crossing the border diminish? What will aliens already here but ineligible for legal status do? Will efforts to mechanize labor-intensive farm operations be accelerated?

The new law is not, of course, the sole factor affecting answers to these questions. Employer sanctions for hiring unauthorized workers will tend to reduce employment opportunities that "pull" aliens across the border. On the other hand, the new law does not treat the primary "push" factor, the dearth of earning opportunities in Mexico. Expanded employment opportunities in the nonfarm sector in the U.S. economy might attract unauthorized aliens in this country directly, or indirectly by bidding legal workers away from agricultural jobs.

The Immigration Reform and Control Act of 1986 can be viewed as a brave social experiment with no precedent. Through responses of employers and aliens it will yield an array of outcomes, private as well as public, social as well as economic, long-term as well as short.

Howard R. Rosenberg is Agricultural Personne Management Specialist, and John W. Mamer is Labor Economist, Cooperative Extension, University of California, Berkeley. 